\title{
Representaciones en los medios impresos: movimiento indígena y paro nacional en Ecuador
}

\section{Resumen}

Diego Pérez

FLACSO Ecuador.

dperezofi@gmail.com

Fecha de finalización: 28 de agosto de 2020. Recibido: 8 de septiembre de 2020 Aceptado: 9 de noviembre de 2020 DOI: https://doi.org/10.26422/aucom.2020.0902.per

En concordancia con la Ley Orgánica de Comunicación (LOC) y la Constitución del Estado ecuatoriano, las cuales establecen, en primera instancia, el derecho a la difusión de contenidos que reflejen la cosmovisión de los 17 pueblos y nacionalidades, así como el cumplimiento por parte de los medios de comunicación del desarrollo de una comunicación basada en los principios de interculturalidad y pluriculturalidad, este artículo tiene como finalidad analizar el marco normativo vigente en relación con la producción comunicativa del diario El Comercio en Ecuador, tomando como referencia la protesta social de octubre, que fue un conjunto de manifestaciones, demandas y movilizaciones desarrolladas desde la sociedad civil en oposición a las medidas y paquetes económicos adoptados por el presidente Lenín Moreno. Durante doce días -del 1 al 13 de octubre-, Ecuador, como otros países del continente, se debatieron entre la reactivación de la inconformidad social, la acción colectiva y la movilización social versus la intimidación estatal, el uso de la represión y el desarrollo de una comunicación polarizada con una parte del conflicto. La información recabada expresa la permanencia del estigma y la subvaloración del indígena como sujeto político en dos escenarios: primero, en la disputa por el espacio público, entendido como un campo de tensiones, asimetrías y lucha de clases, y segundo, en el plano de la legitimidad y la participación política, es decir, la construcción del imaginario discriminatorio en contra del indígena desde el discurso mediático. Ambas miradas configuran un uso instrumental de la comunicación por parte de los medios tradicionales, traducido en formas de diferenciación, exclusión social y legitimización de lógicas de acumulación y proyectos hegemónicos. Desde esta perspectiva, se construye un objeto de investigación que da cuenta de la construcción de la participación del sector indígena en el paro de octubre desde la prensa ecuatoriana, en observancia al desarrollo de una comunicación intercultural propugnada por órganos de regulación y marcos normativos, como la Ley Orgánica de Comunicación y la Constitución de Montecristi (2008), denominada de este modo en honor a la ciudad natal del expresidente del Ecuador Eloy Alfaro.

Palabras clave: comunicación, derechos, interculturalidad, ley de comunicación. 


\title{
Representation in print media: the indigenous movement and the national strike in Ecuador
}

\begin{abstract}
Ecuador's Organic Law of Communication (LOC) and its 2008 Constitution promote the production of contents that reflect the worldviews of the country's 17 nationalities and ethnicities, and tasks news media with producing information based on intercultural and pluricultural principles. Our paper analyzes this regulatory framework in the context of how the El Comercio newspaper in Ecuador covered the protests of October 2019. This period was marked by popular demands and unrest, as civil society rose in opposition to the economic policies of president Lenín Moreno. From October 1 to October 13, Ecuador - like other countries in the region was torn between dissent, collective action, and social mobilization, on the one hand; and state intimidation, repression, and biased media coverage, on the other. Our survey reveals the stigmas and belittlement that indigenous peoples continue to face as political subjects. This can be seen both in the dispute over public space - an arena crisscrossed by tensions, asymmetries of power, and class conflict - and in the debate over political participation and legitimacy, where the media discourse has woven a discriminatory imaginary against indigenous peoples. In both cases, communication is instrumentalized by traditional media outlets, contributing to differentiation, social exclusion, and the legitimation of accumulation and hegemony. From this point of view, we give shape to an object of study that can account for how the Ecuadorian press portrayed the indigenous sector's participation in the October protests, and which encourages the development of intercultural communication, as advocated by regulatory bodies and normative frameworks such as the Organic Law of Communication and the Constitution of Montecristi (2008), so called in honor of the birthplace of Eloy Alfaro, Ecuador's ex-president.
\end{abstract}

Keywords: communication, civil rights, interculturality, communication law.

\section{Representações na mídia impressa: movimento indígena e greve nacional no Equador}

\section{Resumo}

De acordo com a lei orgânica de comunicação (LOC) e com a Constituição do Estado equatoriano, que estabelecem, em primeira instância, o direito à difusão de conteúdos que reflitam a visão de mundo dos povos das nacionalidades, bem como o cumprimento por parte do meios de comunicação para o desenvolvimento da comunicação com base nos princípios da interculturalidade e multiculturalismo, este artigo tem como objetivo analisar o marco regulatório atual em relação à produção comunicativa do jornal El Comercio no Equador. Tomando como referência o protesto social de outubro: um conjunto de manifestações, greves e coalizões desenvolvidas a partir da sociedade civil, em oposição ao conjunto de medidas e pacotes econômicos adotados pelo presidente Lenin Moreno. Durante doze dias - do 1 ao 13 de outubro - o Equador, junto com outros países do Cone Sul, debateram entre a reativação da discordância social, a ação coletiva e a mobilização social; versus intimidação estatal, o uso da repressão e o desenvolvimento de comunicação polarizada com uma das partes no conflito. As informações coletadas expressam a permanência do estigma e a desvalorização do indígena como sujeito político em dois cenários; primeiro, na disputa pelo espaço público, entendido como um campo de tensões, assimetrias e luta de classes; e, em segundo lugar, ao nível da legitimidade e participação política; ou seja, a construção do imaginário discriminatório contra os indígenas a partir do discurso da mídia. Ambas as visões configuram um uso instrumental da comunicação na mídia tradicional, traduzido em formas de diferenciação e exclusão social, legitimação de lógicas de acumulação e 


\begin{abstract}
projetos hegemônicos. Nessa perspectiva, constrói-se um objeto de investigação que dá conta da construção da participação do setor indígena na greve de outubro da imprensa equatoriana, em cumprimento ao desenvolvimento de uma comunicação intercultural preconizada por órgãos reguladores e marcos normativos como a Lei Orgânica de Comunicação e a Constituição de Montecristi (2008), em homenagem à cidade natal do ex-presidente do Equador, Eloy Alfaro.

Palavras chave: comunicação, direitos, interculturalidade, direito da comunicação.
\end{abstract}

\title{
Introducción
}

Los esfuerzos por generar un reconocimiento de derechos colectivos por parte de los grupos y movimientos indígenas en el Ecuador apuntan, entre otras demandas, a la necesidad de desmontar una visión dominante en cuanto a las formas de representación desde los medios masivos, las cuales han naturalizado la discriminación hacía los grupos sociales que son minoría; entre ellos los pueblos y nacionalidades indígenas, que han sido objeto de estereotipos y excluidos en los mensajes producidos a través de radio, prensa y televisión (Canterón, 2018, p. 5).

Frente a esta problemática, los grupos indígenas han desarrollado procesos de resistencia en defensa y reconocimiento de la interculturalidad, que parten, según Villalba Salguero y Villagómez Rodríguez (2020), "de la conformación de organizaciones políticas, de los levantamientos y movilizaciones indígenas, y del reconocimiento en la Constitución ecuatoriana como un Estado plurinacional y multicultural" (p. 64). Configurando una lucha que si bien tiene su origen en las bases sociales y en los propios movimientos, también se las debe entender en el campo discursivo y de la comunicación como espacios en los cuales se refuerza, se visibiliza y se interpela la interculturalidad.

En este contexto, la comunicación intercultural se define como un proceso en construcción, "un esfuerzo expreso y permanente que va mucho más allá de la coexistencia o el diálogo de culturas; es (fundamentalmente) una relación sostenida entre ellas" (Ayala, 2011, p. 16); separada, además, del abordaje exclusivamente culturalista y etnocentrista, entendido este último como otra forma de racismo al revés, es decir, de situar las diferencias étnicas como determinantes en la conformación de la sociedad.

Por lo tanto, hablar de interculturalidad implica un esfuerzo constante desde varios actores de la sociedad; una búsqueda continua que tiene como finalidad la superación del racismo, la inequidad y las desigualdades, en aras de fomentar relaciones mucho más próximas al respeto y la igualdad.

No obstante, el verdadero problema, más allá de la construcción semántica del concepto y de los obstáculos en su acepción, radica en un pronunciamiento normativo que acompañe y refuerce los diversos sentidos de la interculturalidad. Para Villagómez Rodríguez y Ramírez Paguay (2018), los principales errores en el manejo de la comu- 
Diego Pérez

Representaciones en los medios impresos: movimiento indígena y paro nacional en Ecuador

nicación intercultural por parte de los medios tradicionales -en este caso, el diario $E l$ Comercio- se producen por desconocimiento.

Esta deficiencia pone de manifiesto la necesidad de replantear una ética de la comunicación, tanto en la formación académica como en el ejercicio profesional del comunicador, a la vez que interpela la labor de los órganos e instituciones estatales, los cuales deben garantizar un sistema de comunicación que asegure el desarrollo de los derechos a la comunicación, la información y la libertad de expresión, además de fortalecer la participación ciudadana, tal como lo establece el artículo 384 de la Constitución del Ecuador.

Asimismo, la Ley Orgánica de la Comunicación LOC (2019) manifiesta:

se entenderá por contenido discriminatorio todo mensaje que se difunda por cualquier medio de comunicación social que haga distinción, restricción, exclusión o preferencia basada en razones de nacionalidad, etnia, lugar de nacimiento, edad, sexo, identidad de género, identidad cultural, [...], que tenga por objeto o resultado menoscabar o anular el reconocimiento, goce o ejercicio de los derechos humanos, incite a la propagación de estereotipos que promuevan cualquier tipo de violencia de género o limite la libertad de expresión de los grupos minoritarios (artículo 61).

Desde esta perspectiva, la presente investigación se centra en analizar la representación del sujeto indígena tomando como referencia el diario El Comercio durante las jornadas de protestas en octubre de 2019 en relación con las disposiciones de la LOC y de la Constitución de Montecristi de 2008, las cuales hacen hincapié en la necesidad de generar un sistema de comunicación social basado en la interculturalidad y el respeto a las diversidades.

Entre los objetivos de la investigación se pretende comprender el grado de influencia de las constituciones y leyes de comunicación en el ejercicio periodístico y en la representación de los sujetos populares, además de reflexionar sobre la evolución del concepto de "interculturalidad" desde el plano normativo hasta la politización de la etnia como una forma de resistencia, y finalmente analizar los condicionamientos estructurales que determinan el ejercicio periodístico en contextos de protesta y movilización social.

Se sostiene la tesis de que las representaciones adoptadas por El Comercio en relación con el pueblo indígena durante las jornadas de movilización en octubre de 2019 no los reconoce como actores populares y políticos, vulnerando la constitución de la República del Ecuador, así como el cumplimiento de la LOC en lo concerniente al respeto de derechos y al tratamiento de información y contenidos relacionados al sujeto indígena, además de deslegitimar su cultura social y política, reafirmando una postura basada en la subvaloración y discriminación transmitidos a la sociedad ecuatoriana a través de estereotipos, simbolismos y estigmatizaciones. 
Austral Comunicación

Volumen 9, número 2 (Diciembre de 2020): 217-248. ISSN 2313-9129

\section{Práctica comunicativa respecto al sujeto indígena}

Quijano (2014) define la "colonialidad del poder" como "uno de los elementos constitutivos y específicos del patrón mundial de poder capitalista, que se funda en la imposición de una clasificación racial/étnica de la población del mundo como piedra angular de dicho patrón de poder" (p. 285); una imposición que se inserta en todos los campos de la vida y en las relaciones intersubjetivas, las cuales son dominadas por un tipo de hegemonía imperante.

En este sentido, el poder -entendido como una relación- configura espacios sociales de explotación, dominación y conflicto en la disputa latente por el control de los ámbitos de la vida y la existencia social.

Uno de esos ámbitos descritos por Quijano (2014) radica en el control de la autoridad y de los instrumentos que se encargan de la reproducción del patrón de relaciones mencionado anteriormente, no obstante:

Hasta las dos últimas centurias, y hasta la irrupción de las cuestiones de subjetividad y de género en el debate, la mirada eurocéntrica no ha podido percibir todos esos ámbitos en la configuración del poder, porque ha sido dominada por la confrontación entre dos principales vertientes de ideas: una hegemónica: el liberalismo; y otra subalterna, aunque de intención contestataria: el materialismo histórico (p. 289).

La visión subalterna -el materialismo histórico- manifiesta que la conformación social se desarrolla sobre la base de las relaciones que controlan y el trabajo y su producción, y que este conjunto de determinaciones procede de la esfera privada.

Por tanto, pensar la dominación en términos ligados al mercado y a la producción permite entroncar las prácticas comunicativas y la labor de los medios tradicionales más allá de su dimensión informativa, y repensarlas como productoras de líneas discursivas que legitiman la acumulación, la jerarquización del poder y la diferenciación social.

Esta aproximación de la colonialidad del poder y de la subalternación como una forma de resistencia al poder hegemónico no es absoluta, ni unívoca ni puede constituirse como una configuración de elementos históricamente homogéneos. Tampoco puede entenderse como un conjunto de acontecimientos ahistóricos, ya que el entramado social ofrece diversas existencias dentro de la misma estructura. En sintonía con el carácter heterogéneo de la dominación, Vásquez (2020) menciona:

\footnotetext{
la colonialidad en el Ecuador estaría caracterizada por la formulación de políticas y el uso selectivo de discursos etnocéntricos, esencialistas, eugenésicos-higienistas, y exotizantes que permiten no sólo la continuidad, sino la recreación de formas de explotación y desigualdad desde la subalternización de sujetos debido a su condición etno-racial (indígenas y afrodescendientes), geo-territorial (campesinos, migrantes), de género o de clase (p. 297).
}

La explicitación de las formas de colonialidad puede, en alguna medida, explicar los marcos de sentidos sobre los cuales se produce y se ejerce la comunicación por 
Diego Pérez

Representaciones en los medios impresos: movimiento indígena y paro nacional en Ecuador

parte de los medios ecuatorianos. El racismo, por tomar un ejemplo, se ha convertido en un medio y un fin que legitima la estratificación social; la desigualdad, por su parte, ha permitido comprender la diferencia.

Bajos estos análisis, las prácticas y producciones comunicativas de los medios, por un lado, reproducen la dominación colonial y subalternación de los sujetos, al mismo tiempo que se mantienen "subordinadas a las relaciones de poder y a las economías de mercado" (Ramírez, 2020, p. 24).

\section{Contexto de la lucha y movimientos indígenas}

La historia colonial y republicana del Ecuador señala episodios de sublevaciones indígenas, tal como lo refiere Moreno (2014), quien expone que la población aborigen fue sometida a una situación colonial por los conquistadores españoles, supeditando los sistemas normativos y religiosos en función de una cultura dominante. Este fenómeno también se observa en La Rebelión de Daquilema de Ibarra (2018), que hace hincapié en un conjunto de revueltas consumadas en el levantamiento indígena de 1871 en la parroquia de Yaruquíes (Riobamba). Ambos son textos referenciales, a los que podemos sumarles Coronel (2011), Ramón Valarezo (1993), Salomón (1980) y Zúñiga (1971). No obstante, ninguno de estos levantamientos o insurrecciones indígenas dan cuenta del desarrollo de una agenda política en términos sustantivos, la creación de partidos o de su constitución como movimiento político, dado que

\footnotetext{
Antes de la creación del Movimiento de Unidad Plurinacional Pachakutik Nuevo País (PK), en 1995, el rendimiento electoral de las fuerzas de izquierda en el Ecuador, a lo largo del vigente período democrático, fue modesto. Su constitución como movimiento político vino precedida por la eclosión, desde 1990, de una serie de levantamientos indígenas, coordinados por la Confederación de Nacionalidades Indígenas del Ecuador (CONAIE), que paralizaron al país y evidenciaron la irrupción política de un actor colectivo que incidiría, en adelante, no solo en el campo de la izquierda sino en la reconfiguración de la comunidad política (Ramírez, 2009, p. 65).
}

Una reconfiguración que, desde los movimientos indígenas, denota su impronta en la politización del conflicto étnico, lo cual representa una extensión en el discurso ortodoxo de izquierda e introduce la preocupación por el tema de la plurinacionalidad.

La construcción de un cuerpo de demandas por parte de los movimientos indígenas se traduce en once principios, "entre los que se destaca el acceso equitativo a tierra, la no discriminación y la inserción de estas poblaciones, bajo el reconocimiento de la plurinacionalidad y la interculturalidad" (Ramón, 1993, como se cita en Villalva Salguero y Villagómez Rodríguez, 2020), las cuales traen como consecuencia mejoras sustantivas a favor del sector campesino con población fundamentalmente indígena. 
Si bien, en primera instancia, la aparición del movimiento indígena en tanto sujeto político $^{1}$ respondió a fenómenos relativos al campo de los movimientos sociales y la acción colectiva de la época -tales como el declive del movimiento de trabajadores y el surgimiento de Movimiento Indígena Ecuatoriano-, así como a la remisión del problema sociológico acerca de la institucionalización o no de los movimientos sociales, existieron también factores de carácter económico-estructural que incidieron en la articulación de demandas ${ }^{2}$ por parte de los grupos indígenas:

La crisis de la deuda externa fue el punto de partida para el desmantelamiento de las políticas de industrialización y de los dispositivos de redistribución de la riqueza social, instaurados por los gobiernos militares desde los años sesenta gracias al descubrimiento de petróleo ${ }^{3}$ (Ramírez, 2009, p. 66).

En la misma sintonía, Ayala (2011) reconoce que, al acelerarse el proceso organizativo de las bases indígenas, se concreta en 1986 la formación de la Confederación de Nacionalidades Indígenas del Ecuador (también conocida como CONAIE), que no solamente aglutinó la movilización de los indígenas, sino que también significó una postura de resistencia popular en contra del neoliberalismo.

El escenario político de finales de los 80 e inicios de los 90 trajo consigo gestiones presidenciales y planes de gobierno que no lograron contener la inestabilidad política, la inflación y el crecimiento de la pobreza. ${ }^{4}$ En gran medida, estas gestiones se debatieron entre las continuas reprogramaciones de la deuda externa y la disminución de la capacidad de acción del Estado en lo concerniente a aplacar las necesidades de sus ciudadanos e incrementar su poder adquisitivo.

En relación con estos fenómenos, la presencia del movimiento indígena se incrementó frente a la elección de representantes en los comicios electorales de la época:

Desde los años 70 y 80 el movimiento indígena ha estado presente con gran fuerza en la política nacional. Por años participó electoralmente en conjunto con el socialismo y otras fuerzas de izquierda. Los primeros dignatarios indígenas de elección popular llegaron a sus puestos en las listas del Partido Socialista y el FADI. En 1996, las tendencias étnicas promovieron la formación del Movimiento Pachacutik, que ha logrado presencia política

\footnotetext{
Se entiende "sujeto político" interpelando a su noción tradicional y asumiéndolo como aquel con la capacidad de desarrollar estrategias y mecanismos que le permitan comprender su realidad y transformarla (Arias Rodríguez y Villota Galeano, 2006).

2 Las altas tasas de crecimiento de la economía, empujadas por el inicio de la era petrolera, se mantuvieron por el efecto que esta provocó. No obstante, debido a los problemas estructurales que se agravaron o surgieron en esa época, esas tasas no eran sostenibles (Baquero Méndez y Mieles López, 2015).

3 Es importante mencionar que previo al levantamiento indígena de los 90 , también existieron esfuerzos por parte de las bases indígenas por reivindicar derechos: impulsadas por las organizaciones de izquierda, surgieron uniones de comunas parroquiales o cantonales. A nivel nacional, la pionera fue la Federación Ecuatoriana de Indios (FEI) fundada en los años 40. Desde los años 60, la Federación Nacional de Organizaciones Campesinas (FENOC) tuvo un gran desarrollo, fundamentalmente en la lucha por la reforma agraria.

4 Según Barreiros, Kouwennar, Teekens y Vos (1988), la pobreza del Ecuador se incrementó en un $21 \%$ entre 1970 y 1990
} 
y con el tiempo se consolidó como el "brazo político de la CONAIE”. En estos últimos años se ha electo un creciente número de indígenas para la representación popular a nivel local, provincial y nacional, en diversas fórmulas políticas (Ayala, 2011, p. 6).

Esta incidencia en la vida electoral del país se entiende debido a las transformaciones legales que marcaron un mayor involucramiento del sector indígena en los comicios de la época, particularmente la inclusión del voto facultativo para analfabetos establecido en la Constitución de 1978, dado que "desde entonces los indígenas se convirtieron en un sector potencialmente interesante para las campañas políticas" (Guerrero Cazar y Ospina, 2003, p. 5).

A este fenómeno hay que sumarle la elección de Alberto Andrango, intelectual indígena, en calidad de concejal de Cotacachi, además de la figura de Manuel Naula, indígena evangélico apoyado por el partido Izquierda Democrática, quien se transformó en el primer diputado nacional indígena. De este modo, y en palabras de Guerrero Cazar y Ospina (2003), las provincias de Imbabura, Chimborazo y el cantón Saraguro en Loja tuvieron una participación electoral preponderante.

La lucha indígena, según este análisis, se puede entender en tres momentos:

a. Entre 1920 y 1950 se desarrolló una lucha sustentada en el campesinado y en las reivindicaciones por reformas agrarias y superación de formas precarias de producción. En gran medida, esta lucha fue tutelada por el socialismo y la izquierda de la época, que ponen en evidencia la situación del indígena como tema de debate. Esto, sumado al incremento de la presencia estatal en zonas de la Amazonia en aras de insertar a los grupos de esta región al sistema educativo.

b. En los últimos años del siglo XX, según Ayala (2011), las organizaciones pasaron del reclamo por la tierra a un proyecto político más amplio, de pertenencia étnica, seguido de un proceso de movilización por la valoración de sus demandas e interpelación al modelo de ajuste neoliberal. ${ }^{5}$ En resumen, esta fase se caracteriza por un reconocimiento de su agencia política y sus reivindicaciones.

c. Para inicios de este milenio, las demandas se tradujeron en el desarrollo de una educación basada en el lenguaje original de estos pueblos, como una herramienta que permitiera asegurar su identidad y la garantía del ejercicio de sus derechos. Los esfuerzos de unidad y de integrar la diversidad del país en un mismo horizonte se entienden a partir de la propuesta de un proyecto de educación intercultural bilingüe, en el que la interculturalidad es entendida como una construcción permanente, que sobrepasa el diálogo y la convivencia entre culturas, que apuesta más bien a una relación entre ellas en aras de producir sociedades participativas y equitativas.

El rechazo a la agenda neoliberal se había constituido, ya para entonces (1992), en el nudo articulador de sus iniciativas colectivas y discursos políticos. Así lo puntualiza Ramírez (2009). 
No obstante, el concepto de "interculturalidad" sigue en construcción y no deja de ser interpelado -como en su momento lo fueron los conceptos de "multiculturalidad" y "pluriculturalidad"-, lo cual se corresponde con un esfuerzo académico para lograr una mayor precisión y un uso adecuado de este, al tiempo que se delimita una franja divisoria frente a cualquier conceptualización en la que la interculturalidad siga siendo una herramienta de dominación servil a los intereses del mercado.

\section{La Constitución de Montecristi y la Ley Orgánica de Comunicación respecto al sector indígena}

Las continuas movilizaciones lideradas por el Movimiento Indígena Ecuatoriano (MIE) en los últimos años del siglo XX y la ampliación de sectores movilizados que participaron en el derrocamiento del presidente Abdalá Bucaram (1997) dan cuenta de la agitación política de aquellos años, sumado a la necesidad, por parte de los colectivos movilizados, de una extensión en el sistema de derechos frente al planteamiento de una facción más conservadora que defendía la intensificación del modelo presidencialista. En ese escenario, la Constitución de 1998, siguiendo a Ramírez (2009), expresó finalmente algo de las dos propuestas confrontadas: legitimó la agenda reformista y extendió más derechos. Sin significar, necesariamente, la declaración de un Estado plurinacional pese a reconocer y extender los derechos colectivos.

Hasta la Constitución de 1998, Ecuador se establecía como un Estado pluricultural y multiétnico, situación que puede entenderse como un avance importante en materia de visibilización y reconocimiento de la diversidad cultural plasmada en una constitución, generando una amplia lista de derechos colectivos en lo concerniente a lenguas, educación y salud. No obstante, este desarrollo no se manifestó de forma similar a nivel de políticas públicas y ante la ley, fenómeno que acarreó una crisis en los órdenes institucionales. Como advierte Grijalva (2008):

A la Constitución de 1998 no precedió ni siguió el desarrollo de un constitucionalismo plurinacional e intercultural, ni un proceso de constitucionalización general y efectivo. $\mathrm{Ni}$ los legisladores, ni el ejecutivo, ni el Tribunal Constitucional y otras instituciones públicas de defensa de derechos humanos asumieron efectivamente en su actividad los principios constitucionales de diversidad cultural y étnica (p. 55).

A estos obstáculos de carácter constitucional ${ }^{6}$ se le puede sumar una suerte de reduccionismo nominal, el cual, lejos de afianzar la construcción de una sociedad basada en los principios de diversidad cultural, se tradujo en una retórica ineficaz y poco operativa.

\footnotetext{
Un ejemplo de esta falta de desarrollo de la Constitución es el caso de la justicia indígena. Diez años después de dictada la Constitución de 1998, y pese a su expreso mandato de dictar una ley de coordinación de justicia estatal e indígena, esta no se concretó ni se generó casi ninguna jurisprudencia ni institución que coadyuve a la coordinación de las jurisdicciones indígenas y la estatal (Grijalva, 2008).
} 
Otro punto de conflicto radica en la definición de los movimientos indígenas como "pluriculturales plurinacionales", así como el salto cualitativo hacia la interculturalidad.

$\mathrm{Al}$ respecto, Grijalva (2008) menciona que "el movimiento indígena ecuatoriano viene desarrollando desde los años ochenta una definición de los pueblos indígenas como nacionalidades y la consiguiente necesidad de un Estado plurinacional" (p. 55). No obstante, varios sectores de las organizaciones indígenas han interpelado esta denominación, considerada contraproducente a la unidad, y fue rápidamente contrapuesta con el Estado intercultural, interpretado como un Estado que fomenta la inclusión y que empata con los principios de igualdad ciudadana.

Bajo esta lógica, la Constitución (2008) describe al Ecuador como "un Estado constitucional de derechos y justicia social, democrático, soberano, independiente, unitario, intercultural, plurinacional y laico" (artículo 1). Asimismo, la sección tercera, referida a la comunicación y a la información, reza:

\footnotetext{
todas las personas, de manera individual y colectiva, poseen derecho a una comunicación libre, intercultural, incluyente, diversa y participativa, en todos los ámbitos de la interacción social, por cualquier medio y forma, en su propia lengua y con sus propios símbolos (Constitución de la República del Ecuador, 2008, artículo 16).
}

En lo sucesivo, la Carta Magna establece el término “intercultural” en relación con la educación bilingüe, salud, relaciones interculturales, participación, igualdad, organización, inclusión y equidad.

Constitucionalmente, este nuevo documento "elimina las clasificaciones tradicionales de derechos (civiles, políticos, económicos, sociales y culturales)" (Grijalva, 2008, p. 15), amplía la titularidad de los derechos, es decir, permite que las nacionalidades indígenas demanden no solo derechos colectivos, sino todos los derechos estipulados en la constitución, evitando el rechazo de las demandas de estos grupos por parte del Tribunal Constitucional del Ecuador. En otras palabras, se exige a jueces y autoridades el ejercicio pleno de los derechos mencionados.

Antes de indagar sobre el papel que juega la interculturalidad en el desarrollo de la LOC, he considerado pertinente para los fines de la investigación rescatar algunos artículos que se refieren al manejo y producción de contenidos comunicacionales, así como al ejercicio profesional periodístico; ambos en relación con la interculturalidad entendida como una práctica comunicativa.

Dentro del capítulo 1 de la LOC (2013) -específicamente en el artículo 10, numeral 3, literal a- concerniente al ejercicio profesional, se establece que los comunicadores y periodistas "deben respetar los presupuestos constitucionales de verificación, oportunidad, contextualización y contrastación en la difusión de información de relevancia pública o interés general", así como en el mismo artículo, numeral 3, literal b se menciona que los comunicadores deben "abstenerse de omitir y tergiversar inten- 
cionalmente elementos de la información u opiniones difundidas". Dentro del mismo artículo, en referencia a las prácticas de los medios de comunicación social, se expone la necesidad de cuidar la coherencia de los titulares, evitando información ambigua, tendenciosa o que carezca de consistencia con la noticia en cuestión. Adicionalmente, se hace un llamado a la distinción entre contenido editorial, informativo y publicitario.

Según estas premisas, se construye sentido a la comunicación intercultural asumiendo:

\begin{abstract}
El Estado a través de las instituciones, autoridades y funcionarios públicos competentes en materia de derechos a la comunicación promoverán medidas de política pública para garantizar la relación intercultural entre las comunas, comunidades, pueblos y nacionalidades; a fin de que éstas produzcan y difundan contenidos que reflejen su cosmovisión, cultura, tradiciones, conocimientos y saberes en su propia lengua, con la finalidad de establecer y profundizar progresivamente una comunicación intercultural que valore y respete la diversidad que caracteriza al Estado ecuatoriano (LOC, 2013, artículo 14).
\end{abstract}

Revisando de manera exhaustiva la LOC en relación con lo intercultural, nuevamente se hace un llamado a la importancia de desarrollar un régimen de legislación especializado que tenga como finalidad una comunicación inclusiva.

Finalmente, la interculturalidad también se entiende a partir de la participación en igualdad de todas las personas (sociedad civil, comunas, comunidades, pueblos y nacionalidades) a formar parte de los medios de comunicación en condiciones de diálogo, igualdad de género, pluralidad y diversidad.

\title{
Protesta de octubre de 2019
}

Ramírez (2020) denomina "ciclo andino de protestas" al conjunto de manifestaciones y levantamientos visibilizados a finales de 2019 en varios países del Cono Sur, una irrupción que puso de manifiesto la tensión latente entre el desarrollo de Estados neoliberales sustentados en el autoritarismo y las clases populares-precarizadas. En el caso ecuatoriano, estas dan cuenta de la presencia y del surgimiento de nuevas fuerzas sociales que reconfiguraron el escenario de los movimientos sociales y la acción colectiva.

En ese sentido, si bien la construcción de un cuerpo de demandas en contra del paquete de reformas económicas ${ }^{7}$ recogió la participación y la pluralidad de voces correspondientes a varios actores de la sociedad civil (transportistas, trabajadores privados y

\footnotetext{
Le Quang, Chávez y Vizuete (2020) reconocen que: “El martes 1 de octubre de 2019, el presidente de Ecuador, Lenin Moreno, anunció un paquete de reformas económicas con el objetivo de implementar el acuerdo que firmó con el Fondo Monetario Internacional (FMI) en marzo de este año. Una de estas catalizará el rechazo de la sociedad ecuatoriana a nivel nacional: el Decreto 883, que pretendió eliminar el subsidio a las gasolinas diésel y extra (ambas de consumo masivo), que por más de cuatro décadas había logrado contener la estabilidad del precio de los combustibles" (p.53). "En observancia al cumplimiento de una agenda que avanzaba de modo acelerado con despidos masivos en el sector público, golpes a los contratos indefinidos, reducción de indemnizaciones, debilitamiento de las inspecciones de trabajo, etc." (Ramírez, 2020, p. 16).
} 
públicos, colectivos feministas, estudiantes) ${ }^{8}$ dentro de lo que se podría denominar como "paro nacional", el repertorio de acción que simultáneamente aglutinó las demandas de los grupos mencionados se sustentó en el levantamiento indígena, entendido como expresión visible de la resistencia, es decir:

Dicha acción contenciosa (el levantamiento) articula una serie de performances caminatas, marchas, ocupación de las cabeceras cantonales, asedio a edificios públicos, cortes de ruta, rituales identitarios, etc. que suelen terminar con la "toma simbólica" de la capital y algún tipo de interlocución con las autoridades según los elementos del proyecto plurinacional en disputa (Ramírez, 2020, p. 16).

El carácter heterogéneo de "los de abajo", no obstante, se alimentó también de otros lenguajes pertenecientes al mundo del trabajo y a sus mecanismos de resistencia clásicos, dando como resultado un "trastocamiento en los regímenes plebeyos de la lucha social” (Ramírez, 2020, p. 16). Fenómeno que, lejos de deslegitimar la centralidad de la lucha indígena, en realidad la reafirmó en términos de conducción del malestar popular más allá de la demanda étnica, además de fungir como representantes en la reinserción del diálogo con el Gobierno.

Hablar de octubre implica, también, una separación de cualquier tipo de determinismo partidista que condicione el sentido contencioso del despliegue de masas bajo una suerte de tutelaje, e incluso sobrepasa la barrera discursiva y la comprensión analítica en torno a la polarización de la lectura política en términos de correístas y anticorreístas. En realidad, se trata de atender la política emergente en un sentido ampliado, que trasciende las barreras identitarias y se adscribe, siguiendo el razonamiento de Ramírez (2020), como una política del común.

El Gobierno de Moreno, para octubre de 2019, se debatía en una crisis institucional y de legitimidad ${ }^{10}$ como consecuencia de las medidas económicas antipopulares ${ }^{11}$ adoptadas en el marco de un giro político neoliberal, sumado a la incapacidad de gestionar la crisis económica existente, eclipsada bajo el discurso anticorreísta y anticorrupción que para las protestas de octubre carecían de credibilidad entre los electores.

8 Para Chávez (2020), "existen suficientes indicios para suponer que la dinámica específica de la movilización de octubre ocurrió por fuera y en contradicción del 'acuerdo estable’ que sustenta el actual proyecto hegemónico. Se podría decir que esa confrontación provino de dos fuentes también enfrentadas entre sí. Por una parte, las bases del movimiento indígena sumadas a otros movimientos sociales (estudiantes, mujeres, trabajadores no organizados, etc.) y el acumulado del correísmo como proyecto hegemónico alternativo en clave reformista” (p. 345).

9 Denominación empleada por Ramírez (2020) para referirse a los sectores de la sociedad -en su mayoría clases populares- afectados por las medidas determinadas por el Gobierno de Lenín Moreno.

${ }_{10}$ La aprobación de la gestión de Lenín Moreno cayó al 12\% durante las protestas (CEDATOS, 2019).

11 Tras el anuncio de las medidas económicas adoptadas por el Gobierno de Lenín Moreno, emitidas el martes 1 de octubre de 2019 por cadena radial y televisiva, en las cuales se volvió explicita su intención de pactar con instituciones transnacionales (como el Fondo Monetario Internacional) mediante la emisión de decretos ejecutivos y reformas normativas, así como la eliminación del subsidio a las gasolinas diésel y extra, la insatisfacción popular se consumó en contra del gobernante y se tradujo en doce días de fuertes movilizaciones en oposición a estas medidas, consideradas como antipopulares. 
Ambos fenómenos explicitan la ausencia de diálogo con los sectores populares-como, por ejemplo, con el Movimiento Indígena y el Frente Unitario de Trabajadores-, malestar que se tradujo en la emisión de documentos oficiales elaborados por organizaciones sociales que, en palabras de Coronel (2020), describieron al Gobierno de Moreno como determinado por un bloque empresarial y uno transnacional ligado al FMI; el ciclo histórico fue calificado como "una etapa de transición desde el intervencionismo estatal regulador de Correa hacia un intervencionismo estatal desregulador" (p. 311).

En este escenario, y ante la necesidad de generar algún tipo de respaldo a su agenda política, la presencia de las cámaras de comercio ${ }^{12}$ y los medios de comunicación dieron cuenta de un alineamiento con el discurso gubernamental, al mismo tiempo que se reforzó la hipótesis de la inexistencia de fuerzas políticas en las bases de la facción morenista para hacerle frente a la crisis.

La cronología de la protesta de octubre, en palabras de Le Quang, Chávez y Vizuete (2020),

enfatiza en la diversidad de actores sociales movilizados a lo largo del país (transportistas, movimiento indígena, estudiantes, feministas, sindicatos, movimientos políticos, ecologistas, personas no organizadas, entre otros), la variedad de repertorios de acción colectiva empleados (paro de actividades, tomas de edificios públicos, marchas, plantones, cierre de vías, invasión de pozos petroleros, asambleas populares, cacerolazos), y las diversas respuestas estatales (represión, judicialización, criminalización, negociación) (p. 20).

El 1 de octubre se produjo el anuncio de las medidas económicas y otras vinculadas al Bono de Desarrollo Humano, como la reducción de impuestos a los aranceles para maquinaria y tecnología en general. ${ }^{13}$ Rápidamente, la CONAIE y el Frente Unitario de Trabajadores (FUT) convocaron a una rueda de prensa para hacer un llamado a la movilización pacífica, junto a la Federación Nacional de Cooperativas de Transporte Público de Pasajeros del Ecuador (FENACOTIP), con la diferencia de que estos últimos mostraron una mayor radicalidad en su anuncio: el paro nacional comenzaría el 3 de octubre y se desarrollaría por 48 horas.

Un día después, el 2 de octubre, el Legislativo mostró su inconformidad con las medidas tomadas y se desarrolló una movilización gradual en la capital, que con el pasar de las horas se desplegó en varias zonas del país bajo la consigna "no al paquetazo". ${ }^{14}$

El 3 de octubre se resume en el inicio del paro nacional de transportistas, sumado al cierre de vías en varias zonas del país (decisión respaldada por la CONAIE), así

12 Autores como Báez (2020) sitúan la captura empresarial del poder como el inicio del paro nacional.

13 En cuanto a las medidas concernientes al sector productivo, también se eliminaron la salida de divisas, la supresión del anticipo del impuesto a la renta y los aranceles para la importación de tabletas y celulares.

${ }^{14}$ Por "paquetazo" se entiende al conjunto de medidas económicas y pactos con instituciones de crédito desarrollados por los Gobiernos ecuatorianos. Si bien el término tuvo mucha trascendencia en las jornadas de octubre, ya se ha insertado como una consigna central en las protestas y movilizaciones. 
como el desarrollo de plantones convocados por varios sectores de la sociedad civil. Como respuesta, el Ejecutivo declaró el estado de excepción por 60 días.

Clases suspendidas, detención de líderes y dirigentes, disidencia entre las posturas del Partido Social Cristiano ${ }^{15}$ y las cámaras de comercio en torno a las medidas adoptadas definieron el clima de la protesta el viernes 4 de octubre. Esto, sumado al cierre de vías junto a la negociación del sector de transportistas con el Gobierno:

\begin{abstract}
Por la noche, el gremio de transportistas, luego de negar haberse sentado a negociar con el Gobierno en condiciones de estado de excepción, una rueda de prensa en la que pidieron la libertad de sus dirigentes y anunciaron el final del paro. Abel Gómez, de la Federación Nacional de Cooperativas de Transporte Público de Pasajeros del Ecuador (Fenacotip), presentó un manifiesto público junto con los dirigentes de las 11 federaciones de transportistas (El Universo, 4 de octubre 2019). Los principales puntos fueron los siguientes: declararon por terminado el paro nacional; entregaron al Gobierno su petitorio de la derogatoria del Decreto 883; no se responsabilizaron por los actos vandálicos de infiltrados; $y$, finalmente, acordaron con el Gobierno elevar el costo de los pasajes y reducir los impuestos a los insumos para el transporte (Le Quang, Chávez y Vizuete, 2020, p. 62).
\end{abstract}

La ambigüedad de los términos de la negociación entre transportistas y el Gobierno produjo varios anuncios de autoridades municipales, ${ }^{16}$ así como la confusión de la movilidad y el transporte en varias zonas del país. Finalmente, el FUT y la CONAIE anunciaron su alianza y dieron por finalizado los sucesos del 5 de octubre.

El 6 de octubre se debatió entre el montaje de varios centros de acopio por parte de estudiantes y colectivos y el amedrentamiento de fuerzas militares en contra de comunidades indígenas en varias zonas del país para evitar su presencia en la movilización. Luego, el lunes 7, se produjo la llegada de diversas organizaciones indígenas a la capital, junto a una intensificación de las movilizaciones en todo el país. El punto álgido de las protestas en ese momento desembocó en plantones en contra de los medios de comunicación, así como un ataque al edificio de la Contraloría General del Estado. Las autoridades deciden decidieron Guayaquil.

El 8 de octubre se intensificó el repudio en contra de la movilización popular. En gran parte, ese día se puede traducir como la alineación discursiva de las bases conservadoras y de derecha en respaldo al Gobierno de Moreno. La inviabilidad del diálogo entre indígenas y el Gobierno se mantuvo mientras no se derogara el Decreto $883^{17} \mathrm{y}$ se destituyera de sus cargos a la ministra de Gobierno, María Paula Romo, y al ministro de Defensa, Oswaldo Jarrín. Así, aumentaban la represión y la violencia.

\footnotetext{
15 El Partido Social Cristiano, también conocido como PSE, se reconoce como el partido de derecha más grande del Ecuador.

${ }^{16}$ La alcaldesa de Guayaquil, Cynthia Viteri, manifiesta que "la verdad podría resumir en una sola, la verdadera medida que tomó el Gobierno es que acaba de subir los pasajes de transporte público y de carga en todo el país, y por tanto del costo de la vida" (Cynthia suspende su competencia..., 2019).

17 El Decreto 883 establecía el alza de la gasolina y del diésel.
} 
Para el 9 de octubre, en plena conmemoración de las fiestas de Guayaquil, se desarrolló la huelga nacional liderada por el MIE. En Guayaquil se llevaron a cabo dos marchas: una que respaldaba la huelga nacional y otra convocada por la alcaldía de la ciudad bajo la consigna "Guayaquil por la Patria".

El 10 de octubre marcó un tinte sangriento: la protesta comenzó a cobrarse vidas humanas. Se montaron capillas ardientes en el Ágora de la Casa de la Cultura. ${ }^{18} \mathrm{El}$ MIE lo declaró día de luto y periodistas fueron detenidos en los albergues improvisados como respuesta a una cobertura parcializada de los medios tradicionales, los cuales no reflejaban lo que acontecía en las zonas de conflicto. También se destaca la captura injustificada de 19 extranjeros, suceso que es problematizado por Vásquez (2020):

El discurso anti-venezolanización que promovieron las fuerzas integrantes del pacto neoliberal dentro de su agenda económica, proporcionó un recurso para procesar otra crisis: la migratoria. No obstante, la ficticia venezolanización que habían acusado las elites adquiría rostro en los migrantes venezolanos que cruzaban las fronteras (p. 290).

El 11 de octubre, el discurso de las cámaras se intensificó para reactivar cuanto antes las actividades productivas, así como la judicialización hacia los manifestantes. El uso desmedido de la violencia y la represión recrudecieron.

En el penúltimo día de protestas se evidenció una marcha de mujeres alimentada por varios colectivos feministas. La movilización se amplió: más sectores urbanos de la ciudad se comprometieron con la lucha popular. Se declaró el toque de queda y la ciudad se militarizó. Teleamazonas, uno de los medios de comunicación con mayor difusión en el país, y el edificio de la Contraloría sufrieron ataques; ambos episodios reforzaron la postura del Estado de criminalizar la protesta. La fuerte sonoridad de las ollas y cacerolas desafiaba al toque de queda. El MIE aceptó el diálogo con el Gobierno y la Organización de las Naciones Unidas (ONU) ocupó la posición de mediador.

El 13 de octubre, último día, se mantuvo el toque de queda, así como los enfrentamientos entre quienes protestaban y las fuerzas de seguridad. El diálogo no era sinónimo de desmovilización. El acercamiento entre el Gobierno y las bases campesinas e indígenas era una realidad. Una nutrida comitiva acompañó al Ejecutivo, que resolvió la tan ansiada derogación del Decreto 883. Esta resolución fue retransmitida en tiempo real y las bases sociales experimentaron una sensación ambivalente.

Le Quang, Chávez y Vizuete (2020) concluyen que, a nivel informativo,

El unilateralismo mediático de las empresas de comunicación privadas que se observó en el Ecuador desde el estallido de estas jornadas ha imposibilitado contar con información instantánea, completa y del todo veraz sobre los acontecimientos. Los medios privados actuaron en bloque para respaldar al Gobierno, al tiempo de desprestigiar a los movili-

\footnotetext{
${ }_{18}$ El Ágora de la Casa de la Cultura, en Quito, se ha convertido en un espacio para albergar manifestantes y colectivos en contextos de protestas y paros nacionales.
} 
zados y las protestas: aquello supuso que, básicamente, no cubrieran lo que pasaba con la evolución de la protesta (p. 54).

Por su parte la labor de los medios comunitarios y espacios de comunicación alternativa -muchos de ellos liderados por miembros de la sociedad civil-mantuvieron su centralidad en ser portavoces y cronistas del acontecer real de la protesta, lejanos al cerco informativo impuesto por los medios masivos de comunicación.

Esta suerte de contraste en el manejo de la información permitió profundizar sobre varios aspectos de las jornadas de protestas, enfatizando en la necesidad de un ejercicio crítico frente a los contenidos impuestos que catalogaban al paro bajo determinismos como "indigenización de la protesta", "revuelta criminal", "células del correísmo"19 y "partidistas". Asimismo, permitió dar cuenta de la diversidad de actores e instancias mostrados en el conflicto, así como de la explicitación de los repertorios de acción utilizados por bases populares e indígenas. Finalmente, mostró la inviabilidad de la aplicación de regímenes neoliberales en relación con el ejercicio democrático y el desarrollo de derechos colectivos.

\section{Material y métodos}

Para introducir la influencia decisiva de los medios de comunicación en el manejo y tratamiento de la información durante los días de revuelta popular, es fundamental entender la coyuntura política en la cual se adscribe la gestión presidencial de Moreno, por lo que se ha considerado necesario partir de la categoría de frame, tomado como una herramienta metodológica que, por un lado, permite entender las interacciones sociales en términos de significados y prácticas compartidas, pero, por otro lado, también "nos permite encuadrar la experiencia social" (Goffman, 2006, p. 10). Por tanto, retomar dicha categoría nos es útil para encuadrar y dar sentido a la relación entre medios de comunicación, representación y marcos normativos en torno a la protesta de octubre, tanto de manera cognitiva como también referido a la participación de los actores sociales.

La metodología empleada es de enfoque mixto, dado que nos interesa indagar cómo las representaciones de los medios de comunicación, en torno a la protesta y al sujeto indígena, construyen marcos de sentido y de interpretación de la realidad en los espectadores, pero también tener la posibilidad de generalizar los resultados encontrados en un grupo hacia una colectividad mayor (Hernández Sampieri, 2006). No obstante, y en sintonía con Ragin (1994), la diferencia entre un enfoque cualitativo

\footnotetext{
19 Término que hace referencia a los diez años de mandato (2007-2017) liderado por el Gobierno progresista de Rafael Correa Delgado.
} 
y uno cuantitativo no radica en que el primero se centra únicamente en palabras y el segundo en número, sino que

todos los investigadores sociales deben ocuparse tanto de las palabras como de las cifras en algún grado. La diferencia entre la investigación cuantitativa y la cualitativa no está en la oposición entre números y palabras, sino en el simple hecho de que los investigadores cuantitativos se concentran normalmente en los vínculos entre un conjunto menor de atributos presentes en muchos casos cuando construyen su representaciones de la vida social, mientras que los investigadores cualitativos lo hacen en los vínculos existentes entre un gran número de atributos presentes en relativamente pocos casos (p. 21).

La técnica seleccionada fue de análisis de contenido, ya que "permite extraer información a través de análisis minuciosos y profundos de determinados contextos [...], consiste en la descripción de las comunicaciones de forma sistemática y objetiva" (Colás Bravo, 1998, p. 81). De igual manera, permite la extracción de datos objetivos como fase anterior al desarrollo de criterios valorativos, lo cual, a criterio de Aguayo (2018), permite integrar en el análisis las fases cuantitativas y cualitativas, superando así la falsa dicotomía entre los enfoques cualitativo y cuantitativo.

La fuente investigada es el diario El Comercio, que si bien es considerado el segundo medio con mayor tiraje en el país, según Villalva Salguero y Villagómez Rodríguez (2020), al mismo tiempo se reconoce como el medio impreso nacional de mayor influencia y credibilidad.

En cuanto al monitoreo de la información, se realizó una cohorte tomando como referencia los días de protesta (del 1 al 13 de octubre), partiendo del anuncio de las medidas económicas en cadena nacional hasta la negociación entre representantes indígenas y el Gobierno ecuatoriano, acontecimiento que puso punto final al conflicto.

El diario en cuestión arrojó 233 resultados en torno a la protesta de octubre en la delimitación señalada. No obstante, de ese total se tomaron en cuenta artículos periodísticos (189) que dieran cuenta de la representación de los movimientos indígenas en la protesta de octubre, como también acontecimientos ligados a su presencia en la ciudad y en varios puntos del país. ${ }^{20}$

Los criterios utilizados en la selección de artículos fueron a través de palabras clave, como "protesta social", "octubre", "movimiento indígena" y "paro y revuelta social". De igual manera se seleccionaron los formatos de artículo y nota periodística.

La sistematización de esta información parte de la premisa de que existe un conjunto de significaciones construidas por parte de los medios de comunicación -fundamentalmente de la fuente seleccionada- hacia el pueblo indígena, las cuales, para

\footnotetext{
${ }^{20}$ Según el reporte oficial emitido por el Servicio Integrado de Seguridad ECU 911, a cargo del monitoreo de todo el país, durante las jornadas de protestas se evidenciaron 392 puntos de cierre en vías estatales y 1.228 bloqueos en rutas internas urbanas y rurales a nivel nacional.
} 
Diego Pérez

Representaciones en los medios impresos: movimiento indígena y paro nacional en Ecuador

facilitar su comprensión, han sido clasificadas bajo las categorías: estereotipos, antagonismos, imaginarios y simbologías.

Si bien no existe un significado unívoco de "estereotipo", para los fines de esta investigación y tomando en cuenta la influencia de los medios de comunicación en el desarrollo de representaciones, Mackie (1973, como se cita en González, 1999) lo define como un conjunto de "creencias populares sobre los atributos que caracterizan a un grupo social (por ejemplo, los alemanes, los gitanos, las mujeres), y sobre las que hay un acuerdo básico" (p. 79).

Partiendo de los estudios posestructuralistas de Ernesto Laclau, y entendiendo la influencia de los antagonismos en la institución del orden social, se entiende "antagonismo" "como la presencia del otro que impide a una identidad ser ella misma"' además de que "el antagonismo produce la repolitización de la sociedad a partir de un acto de subjetivación e introduce un conflicto en y por el ordenamiento [social]" (Retamozo y Stoessel, 2014, p. 30).

Los imaginarios, por su parte, y siguiendo el razonamiento de Randazzo (2012), se definen como una base social que concentra las representaciones del mundo real, construyendo una forma de ver el mundo y proporcionando referencias de la convivencia social, además de que como herramienta metodológica "permiten buscar entre las formas en que se describen las cosas, aquellas capaces de crear nuevas realidades sociales" (Randazzo, 2012, p. 77).

Finalmente, la categoría de simbologías se concibe como un vehículo para la transmisión de conocimientos y saberes entre los individuos mediados por el lenguaje, además de tener "la capacidad de tomar distancia con respecto al mundo de lo inmediato" (Valencia, 2004, p. 156) mediante la construcción de universos distintos de la realidad, cualidad propia de la actividad simbólica.

\section{Resultados}

El monitoreo realizado dio cuenta de la existencia de 189 artículos, distribuidos de la siguiente manera a lo largo de los días de protesta (ver Tabla 1): 
Austral Cmunicación

Volumen 9, número 2 (Diciembre de 2020): 217-248. ISSN 2313-9129

Tabla 1. Distribución del universo de estudio ${ }^{21}$

\begin{tabular}{lc}
\hline Fecha de protesta & Número de publicaciones \\
\hline 1 de octubre & 0 \\
\hline 2 de octubre & 0 \\
\hline 3 de octubre & 0 \\
\hline 4 de octubre & 1 \\
\hline 5 de octubre & 5 \\
\hline 6 de octubre & 12 \\
\hline 7 de octubre & 31 \\
\hline 8 de octubre & 32 \\
\hline 9 de octubre & 36 \\
\hline 10 de octubre & 28 \\
\hline 11 de octubre & 18 \\
\hline 12 de octubre & 19 \\
\hline 13 de octubre & 7 \\
\hline
\end{tabular}

En el desarrollo de esta compilación, llama la atención la ausencia de artículos que hagan referencia al movimiento indígena durante los primeros tres días de octubre.

El ejercicio del periodismo y la comunicación reposa sobre el cumplimiento de políticas públicas de comunicación; tal como lo reconoce la Constitución de 2008, el Ecuador es un Estado constitucional de derechos que garantiza, entre otros, el derecho a la interculturalidad y a la pluriculturalidad, además de definir la comunicación en términos de "participación", "inclusión" y "diversidad". Asimismo, el propio código deontológico de El Comercio establece:

\begin{abstract}
Está prohibida toda expresión racista, regionalista, chauvinista y despectiva sobre etnias, religiones o minorías. El grupo El Comercio reconoce la diversidad de regiones, pueblos, culturas de conformidad con las normas constitucionales del Estado ecuatoriano, que es democrático, multicultural y multiétnico. El grupo El Comercio respeta el desarrollo de todas las lenguas, donde el castellano es el idioma oficial, pero el kichwa, el shuar y otras lenguas son de uso oficial para los pueblos indígenas (Grupo El Comercio y Ecuadoradio, s.f., p. 8).
\end{abstract}

No obstante, las prácticas comunicativas desarrolladas por el diario suponen un gran distanciamiento respecto a lo establecido por la LOC y la Constitución de

${ }^{21}$ Las tablas y figuras son de elaboración propia. 
Diego Pérez

Representaciones en los medios impresos: movimiento indígena y paro nacional en Ecuador

Montecristi, dado que los marcos de sentido desde donde se configura el entramado discursivo son ajenos a la construcción de contenidos interculturales. Es decir, se aprecia una narrativa que cierra cualquier aproximación a la interculturalidad y a sus principios, a no ser desde la exotización, la estereotipación y el caos urbano.

Para dar cuenta de este fenómeno, se han dividido los artículos en las categorías ya mencionadas. En la Tabla 2 se observa la cantidad de publicaciones según cada una de ellas.

Tabla 2. Cantidad de artículos publicados por categoría

\begin{tabular}{lc}
\hline Categorías & Número de publicaciones \\
\hline Antagonismos & 93 \\
\hline Imágenes & 72 \\
\hline Estereotipos & 19 \\
\hline Simbologías & 5 \\
\hline
\end{tabular}

En este sentido, se evidencia que, del universo total de publicaciones, el 49,20\% ha sido clasificado bajo la categorización de antagonismos (ver Figura 1), es decir, la oposición de elementos considerados incompatibles. Esta relación se manifiesta al momento de polarizar las acciones del sector indígena durante las protestas de octubre como opuestas a los intereses de las mayorías o de la población que no participó directamente en las movilizaciones. Desde luego, uno de los extremos se representa desde lo negativo, lo extraño, lo que no se debe hacer, mientras que su antípoda se asemeja a lo deseable, lo correcto y lo ético.

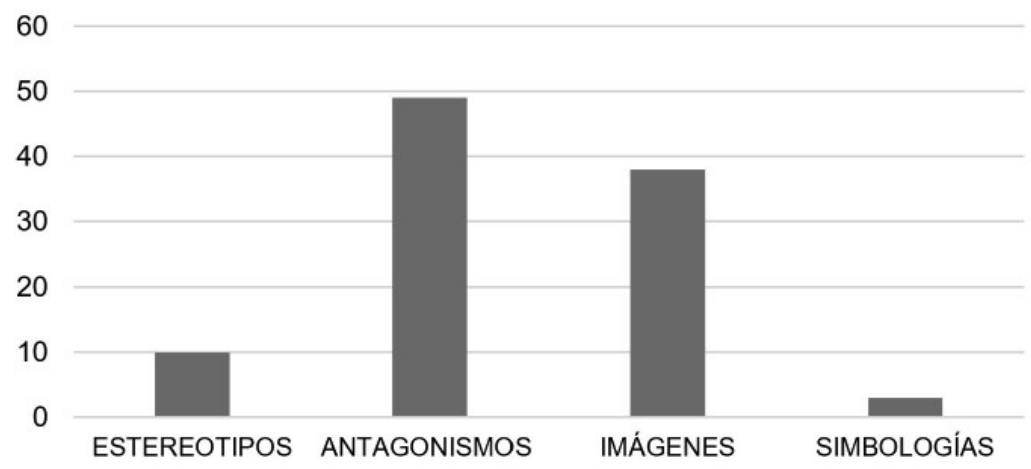

Figura 1. Presencia en porcentajes de artículos periodísticos por categoría. 
En función de la información recabada, este antagonismo puede interpretarse bajo la configuración de una realidad (la protesta de octubre) que se enfrenta con el discurso del grupo "proproducción"-encarnado en cámaras de comercio, organizaciones, dueños de negocios e industrias-, los cuales constituyen el $22 \%$ dentro de esta categoría, tal como lo muestra la Tabla 3:

Tabla 3. Cantidad de artículos publicados por el grupo proproducco
\begin{tabular}{ll}
\hline Grupo & Número de menciones \\
\hline Comerciantes & 2 \\
\hline Federación de industrias & 1 \\
\hline Sector turístico & 1 \\
\hline $\begin{array}{ll}\text { Productores } \\
\text { Corporación Financiera Nacional }\end{array}$ & 2 \\
\hline Cámaras de comercio & 1 \\
\hline Cámaras de producción & 1 \\
\hline
\end{tabular}

Esto se encuentra en oposición a los destructores del patrimonio y de la propiedad privada, evidenciados en manifestantes y, fundamentalmente, en el sector indígena, que representan el 78\% (ver Figura 2).

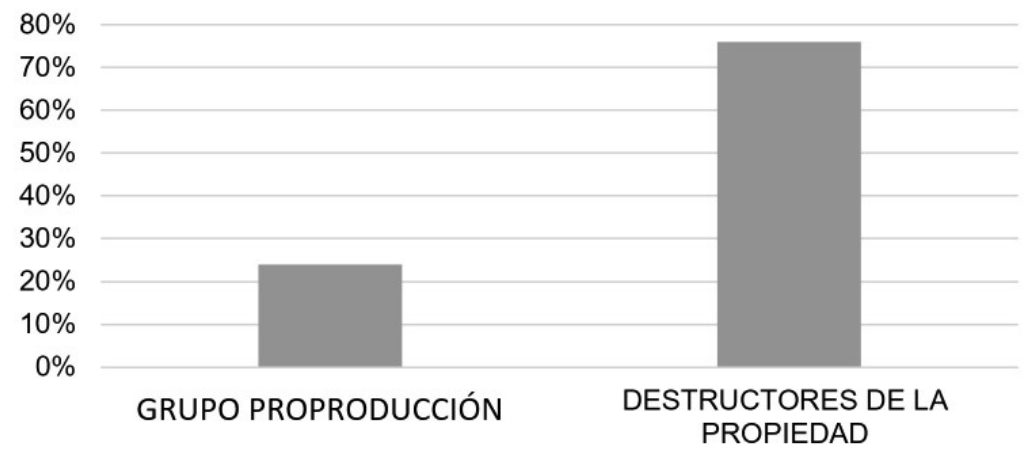

Figura 2. Antagonismo entre grupos proproducción y defensores de la propiedad.

Los primeros son representados como defensores de la democracia y del progreso, los cuales se oponen a cualquier tipo de movilización que vaya en contra de la seguridad y del bienestar de los ciudadanos. Los segundos, en cambio, son retratados como 
generadores del caos y del pánico social. Desde esta perspectiva, el uso del antagonismo tiene dos objetivos claramente marcados: por un lado, utilizar la oposición como elemento diferenciador y excluyente -objetivo que beneficia al grupo denominado "defensores de la producción y del progreso"-, por otro lado, producir un vaciamiento de sentido en las prácticas y en la propia legitimidad de los manifestantes, en el que el sector indígena es claramente el polo en situación de desventaja.

El 38,10\% de las publicaciones se han sistematizado bajo la categoría imágenes, es decir, un conjunto de representaciones directas que refuerzan los imaginarios respecto a un grupo específico o a una situación puntual. En el contexto de la cobertura mediática de la protesta y las movilizaciones sociales, el desarrollo de imágenes es un recurso informativo con una fuerte incidencia sobre los espectadores o consumidores de información.

Partiendo de la premisa de que la producción de contenidos informativos por parte del diario El Comercio tiende a la estigmatización y a la criminalización tanto de la protesta social como del sujeto indígena, los artículos analizados muestran un conjunto de imágenes que configuran una narrativa para reportar los sucesos de octubre, sintetizados en las siguientes dimensiones: solución del conflicto, organización indígena, otras noticias y muertes y decesos (Figura 3 ).

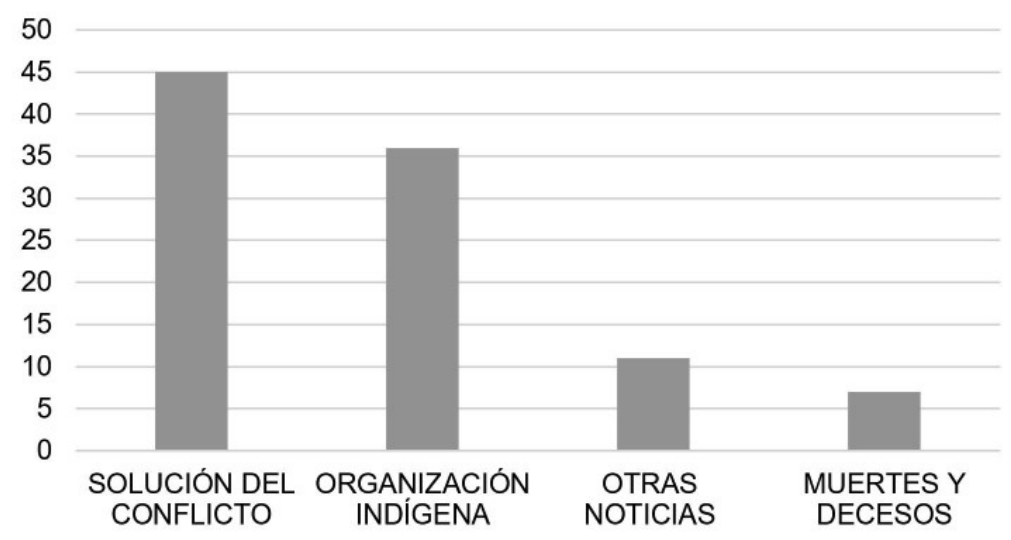

Figura 3. Clasificación de imágenes recopiladas en los artículos periodísticos.

El grupo de imágenes llamado "solución del conflicto" muestra una larga lista de discursos y posturas de instituciones gubernamentales, ONG, partidos políticos, instituciones religiosas y presidentes de diversas naciones latinoamericanas que se manifestaron a favor del diálogo y de la finalización de la protesta social y representa el $45 \%$ de la categoría imágenes (ver Tabla 4). 
Austral Comunicación

Volumen 9, número 2 (Diciembre de 2020): 217-248. ISSN 2313-9129

Tabla 4. Recopilación de discursos oficiales a favor del diálogo y de la finalización de la protesta

\begin{tabular}{ll}
\hline Grupos & Menciones \\
\hline Función de Transparencia & 1 \\
\hline Gobierno de Estados Unidos & 1 \\
\hline ONU & 3 \\
\hline Ministro de Agricultura & 1 \\
\hline Partido Social Cristiano & 1 \\
\hline Asociación de Municipalidades Ecuatorianas & 1 \\
\hline Alcalde de Quito & 1 \\
\hline Presidente de España & 1 \\
\hline Grupos de derechos humanos & 1 \\
\hline Lenín Moreno (presidente de Ecuador) & 6 \\
\hline Conferencia Episcopal Ecuatoriana & 1 \\
\hline Foro para el Progreso de América del Sur & 1 \\
\hline Asociación Interamericana de Prensa 13 de octubre & 1 \\
\hline Pablo Celi (Contralor General del Estado) & 1 \\
\hline Jaime Nebot & 1 \\
\hline Gobiernos locales & 1 \\
\hline Organizaciones de la sociedad civil & 1 \\
\hline
\end{tabular}

En lo concerniente a la configuración de imágenes de la organización indígena en los días de protesta, se puede mencionar que la mayoría de los artículos reportan, a manera de crónica periodística, el proceso de movilización de estos grupos hacia las principales ciudades, así como una recopilación de las principales demandas sin detallar de manera fina ni minuciosa el porqué de estos reclamos, obviando de este modo factores estructurales que dan cuenta del origen y la articulación de estas demandas. En muchos casos, incluso, se presenta el conjunto de peticiones como exageradas, fuera de contexto e injustificadas. Este tipo de imágenes ocupa el 36,11\%.

El apartado denominado "otras noticias" se refiere a un conjunto de artículos periodísticos analizados en función de la influencia de la protesta social en actividades de carácter deportivo, cultural, educativo y tecnológico. La información recopilada concluye en que a raíz de los episodios de protesta, varias de las actividades señaladas fueron canceladas o suspendidas. No obstante, llama la atención que, en varias notas, 
Diego Pérez

Representaciones en los medios impresos: movimiento indígena y paro nacional en Ecuador

la estigmatización de la protesta siguiera presente al considerarla como una interrupción a la normalidad y a la libre movilidad. El apartado mencionado ocupa el 11,89\%, seguido de la clasificación muertes y decesos, en la que se hace referencia a las muertes ocasionadas por la protesta de octubre (fundamentalmente el fallecimiento del líder indígena, Segundo Inocencio Tucumbi) ${ }^{22}$ y la cual ocupa el 7\%.

El 10,05\% pertenece a la categoría estereotipos, en el que se manifiestan representaciones en contra del sector indígena en términos peyorativos. Este fenómeno refuerza no solamente una representación tradicional de estos grupos en los medios impresos, sino que además deslegitima el valor de la movilización social y la presencia de actores políticos indígenas. Estos estereotipos recaen en etiquetas como "aborígenes", "desestabilizadores", "detenidos", "grupos vandálicos", "infiltrados", "procesados", "turba" y "violentos" (ver Tabla 5). Del porcentaje mencionado, en algunas notas de prensa ni si quiera se los visibiliza; no obstante, queda en evidencia un manejo de la información tendenciosa, la cual siempre los representa en una situación de inferioridad o menosprecio.

Tabla 5. Recopilación de estereotipos en las representaciones del diario El Comercio

\begin{tabular}{lc}
\hline Grupo & Número de menciones \\
\hline Aborígenes & 1 \\
\hline Desestabilizadores & 1 \\
\hline Detenidos & 2 \\
\hline Grupos vandálicos & 1 \\
\hline Infiltrados & 1 \\
\hline Irresponsables & 1 \\
\hline Personas infiltradas & 1 \\
\hline Procesados & 1 \\
\hline Turba & 1 \\
\hline Videntos & 1 \\
\hline
\end{tabular}

Finalmente, la categoría simbologías hace referencia al conjunto de representaciones desarrolladas por el diario analizado desde una perspectiva que resalta las tradiciones, rituales y formas de vida de los grupos indígenas movilizados durante el ciclo de protestas.

En ellas se visibilizan -parcialmente- las dinámicas organizativas y de resistencia empleadas por los movimientos indígenas, particularmente en su llegada a Quito y

${ }^{22}$ En la Tarima del Ágora de la Casa de la Cultura (CCE) se montó una capilla ardiente. Allí se colocó el féretro de Segundo Inocencio Tucumbi, manifestante que murió, según la versión de los dirigentes indígenas, en el sector de las universidades (norte de Quito) la tarde-noche del miércoles 9 de octubre (Romero, 2019). 
Austral Comunicación

Volumen 9, número 2 (Diciembre de 2020): 217-248. ISSN 2313-9129

en los momentos más álgidos del enfrentamiento con la policía. Esta categoría ocupa apenas el 2,65\% del universo de publicaciones.

En su artículo 46, la LOC establece que el Sistema Nacional de Comunicación tiene como objetivo "articular los recursos y capacidades de los actores públicos, comunitarios y privados que conforman el Sistema para lograr el pleno ejercicio de los derechos de la comunicación reconocidos en la Constitución".

No obstante, la visibilización de estos actores en el escenario mediático pone de manifiesto una gramática discursiva que carece de un contenido sustancial, en tanto no representa una identificación de capacidades de organización, construcción de agendas políticas y participación en el espacio público.

Si bien el diario El Comercio se ha preocupado por distinguir nominalmente a los diferentes actores del paro de octubre, la mayoría de las acepciones recaen sobre una tipificación que tiende a criminalizar el accionar de estos, junto a la necesidad recurrente de deslegitimar la resistencia a partir de la fragmentación que supone "la trampa de la diversidad". 23

Tomando en cuenta la información recabada, es de destacar la multiplicidad de denominaciones empleadas por el medio de comunicación en torno a la presencia indígena en la protesta (ver Tabla 6).

Tabla 6. Mención en porcentajes de actores en la protesta

\begin{tabular}{lc}
\hline Descripción & Porcentaje \\
\hline Federaciones y confederaciones & 27,32 \\
\hline Muchedumbre & 16,77 \\
\hline Movimientos & 14,28 \\
\hline Líderes indígenas & 12,42 \\
\hline Pueblos y nacionalidades & 9,93 \\
\hline Variaciones en la denominación & 3,72 \\
\hline Comunidades y comunas & 3,1 \\
\hline Uniones 0 asociaciones & 3 \\
\hline Organizaciones & 2,48 \\
\hline Dirigencias & 2,48 \\
\hline Grupos & 1,86 \\
\hline Agencia política & 1,4 \\
\hline Coordinadoras & 1,24 \\
\hline
\end{tabular}

${ }^{23}$ Para Bernabé (2018), la trampa de la diversidad implica un esquema discursivo que tiende a separar o a desvincular las batallas por las luchas de clases. 
El 27,32\% de los artículos pone énfasis en la figura de federaciones y confederaciones indígenas, subdividas a su vez en Confederación de Nacionalidades Indígenas del Ecuador (CONAIE), Confederación de Nacionalidades Indígenas de la Amazonía (CONFENIAE), Confederación de Pueblos de la Nacionalidad Kichwa del Ecuador (ECUARUNARI), Federación de Comunidades Indígenas de Bolívar (FIEB), Federación de Indígenas y Campesinos de la Sierra y Consejo de Pueblos y Organizaciones Indígenas Evangélicos del Ecuador (FEINE).

Le sigue un $16,77 \%$ que engloba la denominación "muchedumbre", es decir, refiere a los manifestantes y bases indígenas en términos ambiguos, como "individuos", "extranjeros", "marcha masiva", "marchantes", "movilizados", "manifestantes" y "sectores de la sociedad".

El 14,28\% correspondiente a la denominación "movimientos" ha vuelto explícita la presencia del Movimiento Indígena de Cotopaxi, del Movimiento Indígena de Chimborazo, del Movimiento Indígena de Tungurahua y del Movimiento de Unidad Plurinacional (Pachakutik).

El $12,42 \%$ se ha referido a los líderes indígenas de la protesta. Las principales menciones, como se observa en la Tabla 7, corresponden a Jaime Vargas (12), seguido de Leonidas Iza (9), Segundo Inocencio Tucumbi (5), Marlon Santi (4) y Salvador Quishpe (4).

Tabla 7. Presencia de líderes indígenas

\begin{tabular}{lc}
\hline Líder & Número de menciones \\
\hline Jaime Vargas & 12 \\
\hline Leonidas & 9 \\
\hline Segundo Inocencio Tucumbi & 5 \\
\hline Mario Santi & 4 \\
\hline Salvador Quishpe & 4 \\
\hline Vicente Chato & 3 \\
\hline Ya ku Pérez & 3 \\
\hline Rosa Rochina & 2 \\
\hline Simón Galán & 2 \\
\hline Geraldo Sac atoro & 1 \\
\hline
\end{tabular}

\begin{tabular}{lc}
\hline Líder & Número de menciones \\
\hline Guillermo Coruchumbi & 1 \\
\hline Hugo Lema & 1 \\
\hline Jaime Chela & 1 \\
\hline Jaime Pallo & 1 \\
\hline Josa Chaluisa & 1 \\
\hline Luis Uhscha & 1 \\
\hline Manuel Catacuago & 1 \\
\hline Miryam Cisneros & 1 \\
\hline Raúl Chilpe & 1 \\
\hline Romelio Gualan & 1 \\
\hline
\end{tabular}


La denominación "pueblos y nacionalidades" también ocupa un lugar importante en esta escala con el 9,93\%, incluyendo la presencia del Pueblo Chibuleo, Salasaca, Sarayacu, Tomabela, Kichwa, Shuar y Quisapincha.

El 3,72\% de la muestra corresponde a "variaciones en la denominación", que contempla: hermano indígena, indígenas evangélicos, indígena y campesino e indígena de buena fe. El 3,1\% es compartido por las denominaciones "comunidades" y "comunas" (comuneros, comunidad indígena de Alausí, comunidades indígenas). Bajo la denominación "uniones o asociaciones" se destacan: la Asociación de Artesanos de Nizag, la Unión de Comunidades Indígenas de Cotopaxi, la Unión Provincial de Comunas y las Comunidades Indígenas de Cañar con el 3\%.

El 2,48\% hace referencia a "organizaciones" -Organización Campesina de Bolívar, organizaciones sociales, organizaciones campesinas e indígenas-, al igual que "dirigencias" (dirigencia indígena, dirigentes políticos). Asimismo, "grupos" evidencia el 1,86\%, incluyendo a grupos de manifestantes y grupos sociales.

En términos de una construcción de una agenda y participación política activa, las denominaciones de actores del paro nacional y líderes políticos ("agencia política") ocupan apenas el 1,4\%. Finalmente, "coordinadoras" -Coordinadora de las Organizaciones Indígenas de la Cuenca Amazónica y coordinadora campesina- representa el 1,24\%

\section{Discusión}

Si bien han existido esfuerzos de carácter constitucional normativo, como lo muestra la Constitución de Montecristi de 2008 así como la Ley Orgánica de Comunicación, en torno al tema de la interculturalidad, el accionar de los organismos constitucionales nunca ha mantenido un compromiso firme para solventar las barreras estructurales que impiden repensar la sociedad en términos de diversidad. La falta de acompañamiento y ejecución de políticas comunicacionales e interculturales en el ámbito jurídico han minimizado las luchas por la reivindicación cultural únicamente al plano nominal, y han incidido en el ejercicio profesional de los medios de comunicación y los periodistas.

A nivel de medios impresos, el sujeto indígena sigue careciendo de una presencia sustantiva más allá de la folclorización y exotización de su identidad, lo cual implica una seria reflexión respecto a cómo se entiende la interculturalidad en el ejercicio mediático y en el reformismo constitucional, además de cómo y bajo qué condiciones se informa a la ciudadanía en sucesos de crisis y estallido social.

Desde esta perspectiva, la cobertura de sucesos y la producción de información por parte del diario El Comercio durante los días de protesta manifiestan una postura explícita y asimétrica frente al desarrollo de conflictos sociales y la emergencia de actores 
Diego Pérez

Representaciones en los medios impresos: movimiento indígena y paro nacional en Ecuador

políticos no tradicionales. Para dar cuenta de este fenómeno, ha sido necesario deconstruir los mensajes y las formas de escenificar al sujeto indígena, mediante la selección de categorías que reflejan la construcción de sentido y de representación de la realidad por parte del medio analizado. Al realizar este ejercicio, se evidencia una narrativa periodística que tiene como fundamento la construcción de antagonismos y una lectura de lo político en términos morales y conservadores. Es decir, la lectura impuesta por el medio analizado entiende a la política "por lo que debería ser" y no por lo que es o se está desarrollando. Niega el carácter contencioso de esta y, por tanto, minimiza los límites de la acción popular y la transformación social en los espectadores.

La constante preocupación del medio impreso por la seguridad y la conservación del patrimonio histórico nuevamente resignifica la presencia de la protesta social en las calles y en las mentes de los ciudadanos, anteponiendo los bienes materiales por sobre el ejercicio efectivo de los derechos en las minorías, además de criminalizar el empoderamiento del espacio público y minimizar los procesos organizativos del pueblo indígena bajo la rigurosa mirada de las élites productoras y de los dueños de la moral. Esta lectura de la protesta a través un actor hegemónico intencional se entiende metafóricamente como una mirada de la realidad con anteojos distintos a los que deberían emplearse. De ahí la desconfianza casi absoluta por parte de movimientos radicales en contra de la función social de los medios de comunicación y el propio constitucionalismo.

Una vez que se identifica la construcción de sentido en las prácticas comunicativas del medio impreso, es necesario conocer los efectos en las audiencias y cómo el consumo y circulación de esta información refuerza el imaginario social y la memoria colectiva. Esta primera lectura en los consumidores de información, aparte de exacerbar el estigma en contra de los pueblos indígenas así como de deslegitimar la protesta social, esconde el factor estructural que guía la generación de contenidos informativos al tiempo que condiciona la labor ética del periodista.

La estructura, en este sentido, es todo aquello que el medio de comunicación esconde y que mediante la estereotipación, la persecución y la criminalización de la protesta y los sujetos insurrectos se constituye en una forma de representar la realidad. Una realidad que, por un lado, evita ponderar los alcances del conflicto social en términos de lucha de clases, surgimiento de nuevos actores sociales, nuevas dinámicas de organización y acción colectiva y reforzamiento de lazos sociales basados en la empatía y las sensibilidades, y que, por otro lado, se convierte en un instrumento de poder, control y organización social, además de legitimar formas de dominación y opresión.

Otro problema que se encuentra en la relación entre medios de comunicación tradicionales y audiencias, que ya se mencionó en líneas anteriores, radica en la tendencia constante de configurar todo suceso informativo en clave de polarización y enfrenta- 
miento. Si bien una de las obligaciones de los comunicadores en torno al tratamiento de la información y el cumplimiento de normas deontológicas tiene que ver con la confrontación de posturas, así como con la contratación de fuentes, en el caso de las manifestaciones de octubre la confrontación se transforma en imposición y adoctrinamiento con una parte del conflicto. La parcialización con los grupos de poder es eminente y se convierte en el sitio de enunciación por parte de estos medios, fenómeno que insta a repensar la realidad de los sujetos excluidos, así como el desarrollo de nuevas formas de concebir el espacio público y vivenciar la interculturalidad.

En ese sentido, cualquier avance constitucional normativo en defensa de la interculturalidad, traducido únicamente en términos de diversidad, resulta inoperante, ya que no permite entender que en muchos contextos la diferencia es sinónimo de desigualdad. Además, el espíritu reformista con el cual se han generado constituciones en favor de la participación de las minorías -fundamentalmente las constituciones de 1998 y de 2008- está atravesado por un legado colonial que sigue reproduciendo formas de dominación impregnadas en las reformas constitucionales.

A ello se le suman la ética periodística y las leyes de comunicación, las cuales, incluso, se han convertido en mecanismos de legitimización de los poderes fácticos, atravesados por la mercantilización de la información y que han fomentado la cuasi desaparición de un ejercicio periodístico a favor de los intereses de las minorías y el resguardo de la democracia. De ahí que la desconexión entre marcos normativos y ejercicio periodístico sea inevitable. Quizá, debido a este fenómeno, el nivel de credibilidad de los medios masivos de comunicación, incluyendo al diario El Comercio, fueron puestos en discusión durante las protestas, fomentado otras formas de informar basadas en el cyberperiodismo y el periodismo ciudadano. En ese sentido, sería muy importante desarrollar investigaciones futuras respecto a la labor de los medios comunitarios y no tradicionales en la revuelta social de octubre.

Instaurada la desconfianza en el constitucionalismo para el cumplimiento efectivo de derechos, el pensamiento académico comienza a replantear una interculturalidad crítica $^{24}$ sustentada en un cuestionamiento continuo de las estructuras institucionales, las democráticas educativas y también las comunicacionales. Bajo este enfoque, es imprescindible pensar la comunicación como un proceso que permita desmontar las formas en las que se expresa la colonialidad del poder desde y con las culturas oprimidas y desiguales, para volver explícita una lógica de dominación que la comunicación tradicional tiende a reproducir y ocultar. De ahí que el rol del comunicador es crucial en la construcción de contenidos comunicacionales éticos y en repensar la cobertura mediática de acontecimientos de interés, con el objetivo de volver reconocibles los

${ }^{24}$ Se retoman los aportes de Catherine Walsh (2012) centrados en repensar las formas de vivenciar la interculturalidad en la actualidad, enfocada en superar las lógicas de dominación en el interior de las relaciones sociales. 
Diego Pérez

Representaciones en los medios impresos: movimiento indígena y paro nacional en Ecuador

condicionamientos estructurales que no permiten la consolidación efectiva de una comunicación basada en la interculturalidad.

\section{Referencias}

Aguayo, N. (2018). La metodología del análisis de contenido y su aplicación en el estudio terminológico de la descripción de la oferta formativa del grado en traducción e interpretación en España. Sevilla: Universidad Pablo de Olavide. https://www. researchgate.net/publication/326295584_La_metodologia_del_analisis_de_ contenido_y_su_aplicacion_en_el_estudio_terminologico_de_la_descripcion_de_ la_oferta_formativa_del_Grado_en_Traduccion_e_Interpretacion_en_Espana/ link/5c8b707f299bf14e7e7cb4a4/download.

Ayala, E. (2011). Interculturalidad: camino para el Ecuador. Quito: Universidad Andina Simón Bolívar.

Báez, J. (2020). Captura empresarial del poder: preludio del Paro Nacional. En Ramírez, F. (ed.). Octubre y el derecho a la resistencia Revuelta Popular y neoliberalismo autoritario en el Ecuador (pp. 195-221). Quito: CLACSO.

Baquero Méndez, D. y Mieles López, J. D. (8 de abril de 2015). Los booms petroleros: qué cambió en los últimos 40 años. Foro Economía Ecuador. Obtenido de http:// foroeconomiaecuador.com/fee/los-booms-petroleros-cambios-40/.

Barreiros, L., Kouwenaar, A., Teekens, R. y Vos, B. (1988). Ecuador: teoría y diseño de las políticas para la satisfacción de las necesidades básicas. Ciudad de México: Instituto de Estudios Sociales y Ministerio de Cooperación de los Países Bajos.

Bernabé, D. (26 de agosto de 2018). La trampa de la diversidad: cómo el neoliberalismo fragmentó la identidad de la clase trabajadora. Obtenido de https://www.akal.com/ libro/la-trampa-de-la-diversidad_48986/.

Canterón, Y. (2018). Análisis de otras dinámicas de comunicación que producen dos medios de comunicación indígenas en Otavalo para explorar otras representaciones del pueblo kichwa (Tesis de Maestría). Obtenido de http://hdl.handle.net/10644/6576.

CEDATOS. (2020). La población evalúa la gestión de los tres años de gobierno del presidente Lenín Moreno. Obtenido de https://cedatos.com.ec/blog/2020/05/23/ la-poblacion-evalua-la-gestion-de-los-tres-anos-de-gobierno-del-presidentelenin-moreno/.

Colás Bravo, P. (1998). La investigación en el campo de la educación. En Colás Bravo, P. y Buendía Eisman, L. Investigación educativa. (pp. 79-90). Sevilla: Alfar.

Constitución de la República del Ecuador. (20 de octubre de 2008). Quito: Asamblea. https://www.oas.org/juridico/pdfs/mesicic4_ecu_const.pdf.

Coronel, R. (2011). Los indios y la revolución de Quito, 1757-1814. Quito: Universidad Andina Simón Bolívar. 
Austral Comunicación

Volumen 9, número 2 (Diciembre de 2020): 217-248. ISSN 2313-9129

Coronel, V.(2020). Crisis de la política del regateo y renovación del movimiento popular ecuatoriano. En Ramírez, F. (ed.). Octubre y el derecho a la resistencia. Revuelta popular y neoliberalismo autoritario en el Ecuador (pp. 309-330). Quito: CLACSO.

Cynthia suspende su competencia de fijar tarifas de transporte público en Guayaquil. (6 de octubre de 2019). La República. Obtenido de https://www.larepublica.ec/ blog/2019/10/06/cynthia-suspende-competencia-fijar-tarifas-transporte-publicoguayaquil/.

Goffman, E. (2006). Frame Analysis: Los marcos de la experiencia (Introducción, pp. 1-21). Madrid: Centro de Investigaciones Sociológicas/Siglo XXI.

González, B. (1999). Los estereotipos como factor de socialización en el género. Comunicar, (2), 79-88. Obtenido de https://www.redalyc.org/pdf/158/15801212.pdf.

Grupo El Comercio y Ecuadoradio. (s.f.). Código deontológico. https://especiales. elcomercio.com/codigo_deontologico/codigo_deontologico.pdf.

Grijalva,A. (2008).El Estado plurinacional e intercultural en la constitución ecuatoriana del 2008. En Ibarra, H. (ed.). Ecuador debate (pp. 49-62). Quito: FLACSO.

Guerrero Cazar, F. y Ospina, P. (2003). El poder de la comunidad. Ajuste estructural y movimiento indígena en los Andes Ecuatorianos. Buenos Aires: CLACSO. Obtenido de http://biblioteca.clacso.edu.ar/clacso/becas/20110120124937/guerrero.pdf.

Hernández Sampieri, R. (2006). Metodologías de la investigación (6 ${ }^{a}$ ed.). Ciudad de México: McGraw-Hill. Obtenido de http://observatorio.epacartagena.gov.co/ wp-content/uploads/2017/08/metodologia-de-la-investigacion-sexta-edicion. compressed.pdf.

Ibarra, H. (2018). La rebelión de Daquilema (Yaruquíes-Chimborazo, 1871). Quito: Instituto Nacional de Patrimonio Cultural.

Le Quang, M., Chávez, N. y Vizuete, D. (2020). El octubre plebeyo: cronología de doce días de movilización social. En Ramírez, F. (ed.). Octubre y el derecho a la resistencia. Revuelta popular y neoliberalismo autoritario en el Ecuador (pp. 53-85). Quito: CLACSO.

Ley Orgánica de Comunicación. (25 de junio de 2013). Quito: Asamblea. https:// www.arcotel.gob.ec/wp-content/uploads/downloads/2013/07/ley_organica_ comunicacion.pdf.

Moreno, S. (2014). Sublevaciones indígenas en la Audiencia de Quito. Desde comienzos del siglo XVIII hasta finales de la Colonia. Quito: Universidad Andina Simón Bolívar/Corporación Editora Nacional.

Quijano, A. (2014). Colonialidad del poder y clasificación social. Buenos Aires: CLACSO.

Ragin, C. (1994). El uso de los métodos comparativos para estudiar la diversidad. En La construcción de la investigación social. Introducción a los métodos y su diversidad (pp. 177-212). Bogotá: Siglo del Hombre Editores/SAGE. 
Ramírez, F. (2009). El movimiento indígena y la reconstrucción de la izquierda en Ecuador: el caso del Movimiento de Unidad Plurinacional Pachakutik-Nuevo País (PK). En Ospina, P., Kaltmeier, O. y Büschges, C. (eds.). Los Andes en movimiento (pp. 65-95). Quito: Corporación Editora Nacional.

Ramírez, F. (2020). Paro plurinacional, movilización del cuidado y la lucha política. Los signos abiertos de octubre. En Ramírez, F. (ed.). Octubre y el derecho a la resistencia. Revuelta Popular y neoliberalismo autoritario en el Ecuador (pp. 11-43). Quito: CLACSO.

Randazzo, F. (2012). Los imaginarios sociales como herramienta. Galicia: Universidad Santiago de Compostela.

Retamozo, M. y Stoessel, S. (2014). El concepto de antagonismo en la teoría política contemporánea. Estudios Políticos, (44), 13-34.

Ramón Valarezo, G. (1993). El regreso de los runas: la potencialidad del proyecto indio. Quito: COMUNIDEC/Fundación Interamericana. Obtenido de http://biblioteca. culturaypatrimonio.gob.ec/cgi-bin/koha/opac-detail.pl?biblionumber=149920.

Romero, D. (10 de octubre de 2019). Indígenas velaron a un manifestante y decidieron radicalizar sus protestas. El Comercio. Obtenido de https://www.elcomercio. com/actualidad/indigenas-velaron-manifestante-radicalizacion-protestas. html\#: :text=Ind\%C3\%ADgenas\%20velaron\%20a\%20un\%20manifestante\%20 y\%20decidieron\%20radicalizar\%20sus\%20protestas,-5781\&text=En\%20la\%20 tarima\%20del\%20\%C3\%81gora,se\%20mont\%C3\%B3\%20una\%20capilla\%20 ardiente.\&text=Ese\%20hecho\%20fue\%20el\%20detonante,Ind\%C3\%ADgena\%20 decida\%20radicalizar\%20su\%20protesta.

Salomón, F. (1980). Los señoríos étnicos de Quito en la época de los Incas. Quito: FLACSOAndes.

Valencia, A. (2004). Norbert Elías y la teoría del símbolo. Sociedad y Economía, (7), 135-157. Obtenido de https://www.redalyc.org/pdf/996/99617647010.pdf.

Vásquez, J. (2020). Raza, migración y crisis: el lugar de la "venezolanización" en el paro nacional. En Ramírez, F. (ed.). Octubre y el derecho a la resistencia. Revuelta Popular y neoliberalismo autoritario en el Ecuador (pp. 287-305). Quito: CLACSO.

Villagómez Rodríguez,P.S.y Ramírez Paguay,E.L.(2018).Abordaje de la interculturalidad en la prensa ecuatoriana. En Herrero, J.y Trenta, M. (coords.).Comunicación y música: mensajes, manifestaciones y negocios (pp. 748-776). Universidad de La Laguna. Obtenido de http://www.revistalatinacs.org/18SLCS/2018_libro/039_Villa.pdf.

Villalva Salguero, T. F.y Villagómez Rodríguez, P. S. (2020).Comunicación intercultural: reflexiones sobre la visibilización indígena en medios impresos ecuatorianos. En Sánchez, R. y Ramírez, M. (eds.). Derechos a la comunicación: ética y competencias del comunicador (pp. 63-89). Quito: Abya Ayala.

Walsh, C. (2012). Interculturalidad crítica y (de)colonialidad: ensayos desde Abya Yala. Quito: Abya-Yala. 